\title{
Psalm 32 as a wisdom intertext
}

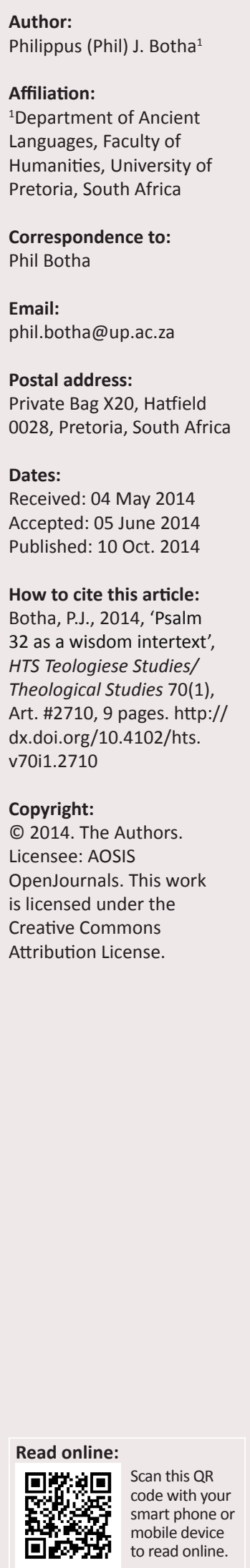

Psalm 32 is considered by the majority of investigators to be a psalm of thanksgiving with a mix of wisdom poetry. In this article, the thesis is defended that it was devised from the beginning as a wisdom-teaching psalm although it simulates the form of a psalm of thanksgiving in certain respects. The case for this is argued on the basis of the complete integration of its parts, as well as its similarity to Proverbs $28: 13-14$ and some other wisdom texts. The aim of the psalmist seems to have been to argue (on the basis of a personal experience) that stubbornness in accepting the guilt of sin causes suffering, but that Yahweh is eager to restore an intimate relationship with those worshippers who confess their guilt and are willing to accept his guidance on the way of life.

\section{Introduction}

There are two implicit claims in the title of this article: that Psalm 32 is a wisdom text, and that it has meaningful intertextual connections with other known wisdom texts. The first claim may not seem difficult to substantiate. The wisdom features of the psalm have been recognised for a long time. ${ }^{1}$ Yet, the psalm is generally still described as a psalm of thanksgiving with wisdom features rather than a wisdom psalm. ${ }^{2}$ Its wisdom features are felt to be 'heterogeneous,' even ill-fitting in the second half of the psalm. ${ }^{3}$ Yet it is also asserted by some that the original psalm (the 'Grundpsalm') was a psalm of thanksgiving already characterised by wisdom and that the two literary types can no longer be 'disentangled. ${ }^{4}$ It will be argued here that the psalm should be read from a wisdom perspective, not a cultic setting of thanksgiving in response to healing after illness. The Gattung and possible setting of the psalm will be discussed in greater detail after its wisdom connections have been considered.

The claim that Psalm 32 has intertextual connections with other wisdom texts, in other words, a literary relationship with other wisdom texts, can also be substantiated, at least partially. Bernard Gosse (2008:67) in his influential book on the redactional influence which the book of Proverbs exerted on other biblical books during the Persian period, singles out as especially notable the connection between Proverbs 28:13 and Psalm 32:5. The Proverbs text reads: 'One who conceals his transgressions will not prosper, but the one who confesses and forsakes (them), will find mercy.' In Psalm 32:5 the author states: 'I acknowledged my sin to you, and I did not conceal my iniquity; I said, 'I will confess my transgressions to Yahweh,' and you forgave the iniquity of my sin.'

In this regard, the article constitutes an investigation to determine whether it is possible to confirm a literary link between Psalm 32 and Proverbs 28:13, and to look for more indications of literary connections with wisdom texts. It is argued that Proverbs 28:13 should be read together with Proverbs 28:14 (to which it is connected in a chiastic embrace) and that Psalm 32 as a whole

1.Its wisdom features are described by Hossfeld as consisting of typical wisdom speech forms (such as the introductory beatitudes, the admonitions of vv. 6 and 9, and the aphorism in v. 10); wisdom vocabulary (such as the reference to 'instruction,' 'teaching' and 'counselling' in v. 8, the 'road' as metaphor for conduct in v. 8, the animal comparisons in v. 9, and the equalising of 'righteous people' with those who are 'upright in heart' in v. 11); and, finally, the presence of wisdom conceptions (such as the contrast between people who trust in Yahweh and wicked people in v. 10, the deed-consequence connection in v. 10, and the generalisation in terms of all humanity in v. 2). Cf. Hossfeld (1993:200). Hossfeld has advanced from the position of Gunkel, who found clear wisdom motifs only from verse 6 onwards. He interpreted the beatitudes in vv. 1-2 as a modified form of confession ('das 'Bekenntnis', das der Dankende vorausgestellt hat, und das die Form eines 'Segenspruches' trägt'). See Gunkel (1986:135).

2.So, for instance, Hossfeld (1993:210), who singles out a foundational psalm in verses 1-5, 7-8, and 11. Weber (2010:179) expresses doubt whether there is a Gattung such as wisdom psalm. He (2010:180) describes Psalm 32 as 'a wisdom song of thanksgiving' (my translation of the German).

3. Hossfeld (1993:200) describes verses 1-5 as having a unified appearance, whilst verses 6-11 are interspersed much more with heterogeneous elements which hardly fit into the composition.

4.Hossfeld (1993:200): 'Mann kann Dank- und Weisheitslied nicht voneinander ablösen und den Endtext durch das Zusammenwachsen beider erklären.' Kraus similarly thinks that wisdom elements played a role already at the conceptualising of this song of thanksgiving. Cf. Kraus (1972:254). The thesis that the psalm is a psalm of thanksgiving intermixed with motifs of wisdom poetry commences with Herman Gunkel (1986:135). For a good review of opinions on the Gattung of Psalm 32, Willmes (1996:28-31) can be consulted. 
can be seen to reflect the teaching of these two verses. In addition to that, there are reflections of other contexts in Proverbs, so that one can argue that Psalm 32 was not only influenced in general by wisdom theology (as even Gunkel would concede), but that Proverbs had possibly already assumed the role of authoritative teaching by the time Psalm 32 was composed. Its genre consequently is not that of a psalm of thanksgiving of an individual, ${ }^{5}$ but a wisdomteaching poem directed at the in-group of the author, intended to encourage members of this group to persevere in their faith by confirming the teaching of Proverbs and applying it to the experience of the author (or implied author). ${ }^{6}$ Even when Yahweh is addressed directly as in verses 6 and 7 , the purpose is to encourage fellow believers to seize the hope created by the psalmist's experience (Wilson 2002:547). Verses 8-9 consequently also do not constitute an oracle of Yahweh in a cultic setting, ${ }^{7}$ but a quotation of the words of Yahweh directed to the faithful, where Yahweh takes over the role of wisdom teacher similar to that of the wisdom teacher in Proverbs. The context of worship in which the psalm would have been used was supposedly not limited to private prayer, but would have included a religious gathering of faithful as in a synagogue. The psalm refers to praying (v. 6), shouts of deliverance 'surrounding' the suppliant (v. 7), the teaching of Yahweh's torah (cf. ירה hiphil in v. 8), and the joyful exultation and shouting of a group of faithful (v. 11). These features indeed suggest a setting of worship, but not a liturgy of thanksgiving in the temple.

The method that will be employed subsequently is to review the structure, textual strategy, and message of the psalm, and then to discuss its literary relationship with other texts from the Hebrew Bible. The use of distinctive vocabulary within the same conceptual representation and with comparable contents will be taken as an indication of possible literary connections. On the basis of its integrated structure and intertextual connections, it will then be argued that the psalm as a whole should be recognised as a composition which was designed to apply the teaching of Proverbs and other wisdom texts for a specific religious community of Yahweh worshippers. Its Gattung will be discussed again just before the conclusion.

5.The features which are usually described as deriving from a song of thanksgiving are more difficult to connect with that Gattung. It is, for instance, inconceivable that the author would present his own thanksgiving in the form of a general beatitude (vv. 1-2), as Gunkel (1986:135) and Nötscher (1953:61) of a general beatitude (vV. 1-2), as Gunkel (1986:135) and Nötscher (1953:61) assert. Delkurt (2010:50) list the following differences between Psalm 32 and the typical hymn of thanksgiving: There is no formula of thanksgiving; there is no mention of a thanksgiving sacrifice; enemies and illness play almost no role; and there is very little information about the personal situation of the suppliant.

6.Weber (2010:186) cautions against a strict division between cult and wisdom stating that one and the same psalm would often display various speech-acts and communicational settings. Those aberrant interpretations of Psalm 32 which read the beatitudes in verses 1-2 as modified forms of thanksgiving, however, serve as a warning against a too rigorous form-critical approach.

7. Hossfeld $(1993: 204)$ describes verse 8 as an oracle with typical wisdom formulation and concerns, but verses 9-10 as a redactional admonition which shows through its address to a group that it is no longer part of the Yahweh-oracle. The structura its aldris shows, how analysis shows, how 9 must be conceived as part of Yahweh's address to 6 all the 10-11, so that verse 9 must be conceived as part of Yahweh's address to all the 'godly' (mentioned in v. 6), 'the one who trusts in Yahweh' (mentioned in v. 10), and 'the righteous' and the 'upright in heart' (both groups of people, mentioned in v. 11). The same objections can be brought against Weiser's interpretation of verses $8-10$ as the words of the psalmist, directed at the community of the faithful. Se Weiser (1955:193).

\section{The text and structure of Psalm 32}

\begin{tabular}{|c|c|c|c|}
\hline \multirow{5}{*}{ A } & & 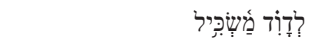 & ${ }^{1}$ A Maskil of David. \\
\hline & \multirow[t]{2}{*}{1} & 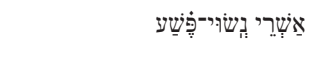 & $\begin{array}{l}\text { Blessed is the one whose } \\
\text { transgression is forgiven, }\end{array}$ \\
\hline & & 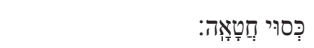 & whose sin is covered. \\
\hline & \multirow[t]{2}{*}{2} & 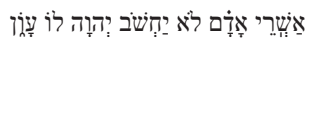 & $\begin{array}{l}{ }^{2} \text { Blessed is the person } \\
\text { against whom Yahweh } \\
\text { counts no iniquity, }\end{array}$ \\
\hline & & 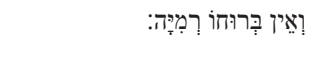 & $\begin{array}{l}\text { and in whose spirit there is } \\
\text { no deception. }\end{array}$ \\
\hline \multirow[t]{5}{*}{ B } & \multirow[t]{2}{*}{3} & 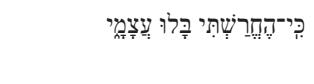 & $\begin{array}{l}{ }^{3} \text { When I kept silent, my } \\
\text { bones became brittle }\end{array}$ \\
\hline & & 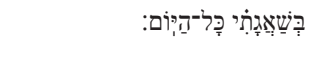 & $\begin{array}{l}\text { through my groaning all } \\
\text { day long. }\end{array}$ \\
\hline & \multirow[t]{3}{*}{4} & 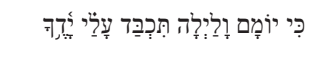 & $\begin{array}{l}{ }^{4} \text { For day and night your } \\
\text { hand was heavy upon me; }\end{array}$ \\
\hline & & 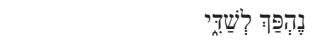 & my strength was changed \\
\hline & & 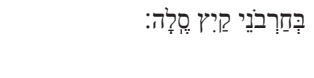 & $\begin{array}{l}\text { as by the dry heat of } \\
\text { summer. Selah }\end{array}$ \\
\hline \multirow[t]{3}{*}{ C } & \multirow[t]{3}{*}{5} & 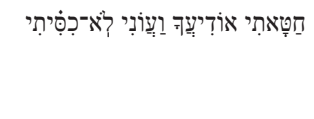 & $\begin{array}{l}{ }^{5} \text { I acknowledged my sin to } \\
\text { you, and I did not conceal } \\
\text { my iniquity; }\end{array}$ \\
\hline & & 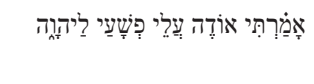 & $\begin{array}{l}\text { I said, 'I will confess my } \\
\text { transgressions to Yahweh,' }\end{array}$ \\
\hline & & 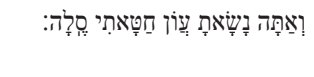 & $\begin{array}{l}\text { and you forgave the } \\
\text { iniquity of my sin. Selah }\end{array}$ \\
\hline
\end{tabular}

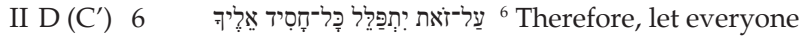

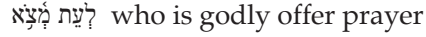
to you at a time when you may be found;

surely in the rush of great waters,

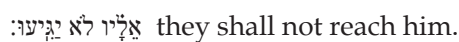

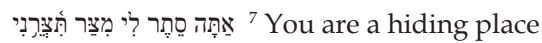
for me; from trouble you preserve me;

רָרני פַלְט with shouts of deliverance

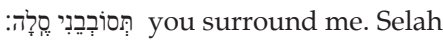

$\mathrm{E}\left(\mathrm{B}^{\prime}\right) 8$

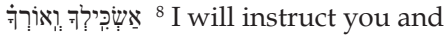
teach you

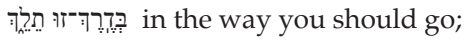

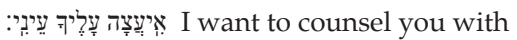
my eye upon you.

99 or a mule, without understanding,

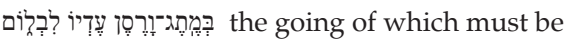
curbed with bit and bridle,

or it will not come near you.

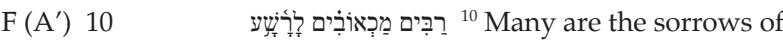
the wicked,

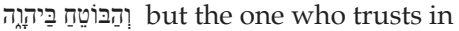
Yahweh,

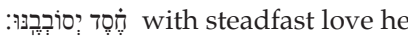
surrounds him

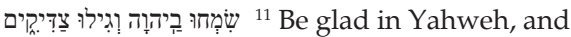
rejoice, $\mathrm{O}$ righteous,

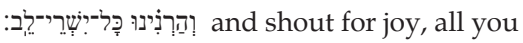
upright in heart! 
The following exposition is given as a summary of the textual strategy and message of the poem. ${ }^{8}$ There is little doubt that the author intended to create two stanzas of equal length. Each stanza has three strophes (A, B, and C for stanza I and D, E, and F for stanza II), of which the first and last in both stanzas are especially tightly interwoven to create an envelope around the middle strophe. The strophes of the two stanzas are also connected with one another in a chiastic pattern (ABC - $\left.\mathrm{C}^{\prime} \mathrm{B}^{\prime} \mathrm{A}^{\prime}\right)$, so that the poem as a whole also constitutes an inclusion.

In stanza I, strophes A and C are tightly interconnected through the repetition of no less than six words: נשא, פשעע, כסה, חטאה ,יהוה and עון The general pronouncement on the state of blessedness of the one whose transgression is forgiven ('lifted') and whose sin is removed ('covered') and against whom Yahweh 'counts no iniquity,' expressed in strophe A, forms a polarity with the suffering in body and soul (cf. 'my bones' and 'my strength' in verses 3 and 4 ) of the suppliant described in strophe B. The suppliant says in this strophe that he had 'kept silent.' In the context of this stanza, החרשתי implies to have kept silent about sin, thus not to have confessed his transgression and thus to have tried to cover up his sin. As a result, he experienced his 'bones' becoming brittle so that he 'groaned' all day long. His 'strength' dried up as by the dry heat of summer, seeing as the hand of Yahweh was 'heavy' upon him. This suffering stopped, it seems, when he acknowledged his sin to Yahweh, when he refrained from concealing his iniquity and confessed his transgressions (plural) to Yahweh (strophe C). Once he did that, a change occurred: he simply says that Yahweh 'forgave' the iniquity of his $\sin ($ v. 5).

Strophe B, the description of the time of suffering, therefore serves to form a junction between strophe A (a general pronouncement on the blessedness of forgiveness) and strophe $\mathrm{C}$ (a report about confession and a personal experience of forgiveness). But strophe B further also has strong connections with strophe $\mathrm{E}\left(\mathrm{B}^{\prime}\right)$, the middle strophe of stanza II. This is the case because of the parallel and inverse structure of stanza II, but also because of the polarity formed between strophes B and E through the contrasting use of certain terms.

The first and last strophes of stanza II also have strong connections, this time because of the repetition of five words

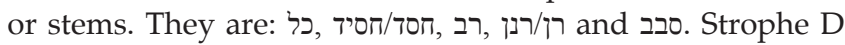
explores the protection offered by Yahweh to the 'pious' or 'godly' people who pray to him at an opportune time: ${ }^{10}$ The rush of great waters will not touch them, ${ }^{11}$ Yahweh serves as

8.This article forms part of a joint investigation with my colleague Henk Potgieter, who assumed responsibility for explicating its structure. His article (Potgieter in press), to be published in the same journal as this article, should be consulted for the detailed analysis.

9. Hossfeld (1993:203) describes this as literally 'an abrasion' of the bones ('die Abnützung der Knochen').

10.At a 'time of finding' (לעת מצא ) מצא in the sense of finding what was sought. Cf. its use in finding God in Deuteronomy $4: 29$. Kraus (1972:257) expresses the
opinion that this phrase, though difficult to understand, definitely relates to Isaiah opinion that this phrase, though difficult to understand, definitely relates to Isaiah
49:8 ('in a time of favour') and 55:6 ('seek Yahweh whilst he may be found'). The
meaning is: 'Wer rechtzeitig zu Jahwe Zuflucht nimmt und sich ihm offfnet, der bleibt unberührt von den Wogen des Verderbens.'

11.Possibly as in a deluge of rain because of God's anger, as is used in Ezekiel 13:13. There may be a literary connection also with Psalm 18:17, where the psalmist tells about Yahweh's drawing him out of 'many waters' (מים רבים), the words also used in Psalm 32:6. a hiding place and he preserves the believer from trouble and surrounds him with shouts of deliverance. The rush of ' great' $^{\prime}$ (רבים) waters in strophe D is connected with the 'many' (רבים) sorrows of the wicked mentioned in strophe F. The 'shouts of deliverance' with which Yahweh 'surrounds' (תסובבני) the suppliant in strophe D connects with the 'steadfast love' with which he 'surrounds' (יסובבנו) the one who trusts in him in strophe F. The godly (כל־חסיד) of strophe D connects semantically and through the repetition of 'every/all' with the righteous (צדיקים) and all the upright in heart (כל־ישרי־לב) of strophe $\mathrm{F}$, but the designation also connects through the repetition of the stem nסד/תסיד wove steadfast love mentioned in strophe F.

The connection between the two middle strophes B and E (or $B^{\prime}$ ) is, in the first place, the fact that the preposition על is used in both to express the relationship between the suppliant and Yahweh. A part of Yahweh's 'body' also features in both strophes. In strophe B, the psalmist is speaking. He says that, when he kept silent, he had to groan all day, given that the hand of Yahweh was 'heavy' upon him (עלי ידך). In strophe E, Yahweh is speaking (in contrast to the suppliant's keeping silent). He is announcing his desire to 'instruct,' 'teach,' and 'counsel' the suppliant (the three verbs indicate an abundance of communication), with his eye upon him (עליך עיני). It would therefore seem that the psalm emphasises the polarity between the 'hand' of Yahweh resting heavily 'on' the suppliant when he kept silent, and the 'eye' of Yahweh keeping watch 'over' the suppliant whilst giving him ample verbal guidance. This happened after the psalmist decided to break the silence by 'acknowledging,' not 'covering' anymore, and 'confessing' his transgressions (thus accepting a stance of complete openness and communication towards Yahweh).

It turns out that the suppliant suffered like a beast of burden. He carried the heavy burden of his transgression, expressed through the stem כבד treat his followers like horses or mules, but would like to interact intelligently with them, instructing and teaching them in the way they should go, counselling them with his eye over them instead of his hand on them. Once the burden was 'lifted' (cf. נשיאת und used as descriptions of the forgiving of sins), this became possible. Keeping silent is therefore equal to acting like an animal (the suppliant only managed to 'groan'); an animal is handled with bit and bridle and a heavy hand ( $\mathrm{v}$. 9). Confessing one's transgressions, on the other hand, is to act intelligently (cf. הבין in v. 9) and in such a relationship one can offer prayer (תפלין, v. 6), be glad (שמחל, v. 11), rejoice (הינח, v. 11), and shout for joy (הרנינו, v. 11). The threefold mention of rejoicing at the end of the psalm was probably meant to reflect the twofold state of blessedness mentioned at the beginning of the psalm (cf. Weber 2001:159), so that the two stanzas also form chiasmus (ABC $\left.-C^{\prime} B^{\prime} A^{\prime}\right)$. The sound play of the double אשרי ('blessed') in strophe A with ישרי־לב ('upright of heart') in strophe F strengthens this perception.

The psalm could therefore not possibly be a haphazard compilation of material from divergent sources, from a

12.Cf. the similarities with Psalm 38:3-5, where the 'hand of Yahweh' is mentioned which 'descended' on the suppliant, and also the iniquities which became too much for the suppliant, being like a 'heavy burden' which weighed him down. 
cultic and a wisdom context with redactional additions. ${ }^{13}$ Its contents were organised carefully and very precisely by a single author or group of authors. ${ }^{14}$ In addition to that, it was carefully edited to fit into its present location by establishing keyword connections with many other psalms from the first Davidic collection (Ps 1-41). ${ }^{15}$ The objective of the poet was to encourage members of his in-group, those who are 'godly' or 'pious' (זסיד), those who 'trust' in Yahweh (הבטח), the 'righteous' (ציקים), and the 'upright in heart' (ישריז) not nביז) not to be rebellious when struck by adversity, but to confess one's transgressions, to pray to Yahweh at a time when he may be 'found,'16 and to foster an open, wise, and close relationship with Yahweh, one in which there is complete trust in him.

\section{A definition of 'intertextuality' in the case of Psalm 32}

Psalm 32 has a variety of intertextual connections. One aspect of its intertextuality would be the fact that it was given the heading לדוד, 'of David,' 'concerning David,' or 'to David' or however the construction should be interpreted. This heading establishes a link with King David whose life and purported compositions ${ }^{17}$ are thereby hermeneutically connected to the text of Psalm 32. A second aspect of intertextuality is the fact that the psalm is described in the heading as a משכיל, a kind of wisdom-teaching song. ${ }^{18}$ This, in combination with its wisdom features, establishes links to the biblical wisdom material and suggests a pedagogical intent. A third aspect of intertextuality concerns the keyword connections established between Psalm 32 and other psalms of the first Davidic collection. ${ }^{19}$ These links, whether they were inserted by the author or by editors who planned the present position of this psalm in the book, also have hermeneutical implications. ${ }^{20}$ They suggest that the

13.Hossfeld (1993:204-205) visualises a cultic background for the "Grundpsalm,' as he calls it. He supposes that confession of sins by the psalmist would have taken place in the temple before Yahweh, but finds no indication in the psalm of the liturgical procedure followed. Verse 8 is interpreted as an oracle of salvation, and he considers it possible that a cultic prophet could have made the declaration. Verse 6 and verses $9-10$ are seen by him as redactional extrapolations of this original psalm. Seybold (1996:134) identifies 'erklärende Zusätze' in 2, 3b, 6, 8aß, $9 \mathrm{~b}$, and $10 \mathrm{a}$.

14.Verses 8-9 could possibly be omitted without affecting the 'thread of the discourse' (according to Norman Whybray), but this would seriously affect the symmetric form. Cf. Whybray (1996:53)

15.See the helpful remarks by Weber (2001:159).

16.There is no convincing reason to understand verse 6 as referring to a time of distress.

17. For example, his sin of adultery and murder, as well as the contents of Psalm 51, in which he is portrayed (through the heading of that psalm) as confessing those sins.

18.This part of the heading is evidently related to the fact that the verb שכל hiphil ('to teach') is used in the psalm. It could in any case not be a designation of the melody, as is suggested by Lamparter (1961:161). This remark should, however, not detract from the otherwise astute exposition of Lamparter.

19.According to Barbiero (1999:424), a new structural unit begins with Psalm 31, and 12 keyword connections link it with the following three psalms, whilst some of these keywords extend even beyond that to Psalm 36. Gerald Wilson points out the similarity between Ps 32 and the suffering of the innocently accused suppliant of Psalm 31, with eyes, soul, and body growing weak; life being consumed with groaning; strength failing and bones growing weak (31:9-10). Cf. Wilson (2002:546).

20.See the explanation of these links for the understanding of Psalm 32 by Barbiero (1999:451-455). Hossfeld (1993:201) ascribes verses 6 and 9-10 to an 'exilic redaction, which sought to point out that Yahweh gives salvation from illness and sin. For that reason 31. In his opinion, the olarity between them into Psalm 32 because they wanted to and requital to the wicked. Verse 6 is also described by Hossfeld (1993:204) as redactional, and the description 'all the godly' is seen by him as serving to connect Psalms 30-32 to one another. psalm forms a unity with its predecessors and successors and should not be read in isolation.

A fourth type of intertextuality and what is especially at stake here is what can be called 'canonical intertextuality.' This refers to the fact that a growing body of authoritative literature was continually in need of explication and exposition, and this stimulated the creation of additional texts speaking with an authoritative voice. ${ }^{21}$ Proverbs 1-9, for example, were understood to reflect the traditions of Deuteronomy in a way which shows how the authors of Proverbs 1-9 had accepted Deuteronomy as authoritative religious instruction and had used it as a mould for their own wisdom teaching in order to establish the idea that their instruction would also be accepted as binding by their own students (cf. Reichenbach 2011:415). Such intertextual links between Deuteronomy and Proverbs can be seen, for example, in the way in which Proverbs replicates Deuteronomy's call to its audience to listen and preserve the teaching given; the way in which these are linked to promises of a prosperous life; and the way in which road imagery symbolises the relationship of the addressees with the teaching given to them (Reichenbach 2011:125-189). In cases where the date and early authoritative nature of texts can be established with reasonable certainty, the direction of influence can be easily inferred. In other instances it is more difficult; whilst the possibility must always be kept in mind that, in the case of more or less contemporaneous texts or over time, the influence could have been bidirectional. In the case of wisdom psalms, for example Psalm 1, there is reasonable consensus that Proverbs (in addition to other books from the Hebrew Bible) provided the stimulus for the composition of the psalm. It will be argued in what follows that Psalm 32 presents the investigator with 'intertextuality' on more or less the same level.

Roland Murphy argues that 'wisdom influence' can be shown through the presence of vocabulary, literary forms, or content typical of wisdom and that one can mount a cumulative argument by drawing on all three these factors (Murphy 1996:98). On the basis of all three these criteria being present in Psalm 32, Murphy classifies Psalm 32 as an 'authentic' wisdom psalm. ${ }^{22}$ The questions which concern us here, however, is not only whether Psalm 32 is a wisdom psalm, but whether the book of Proverbs can be shown to have had an influence on its composition.

\section{The connections between Proverbs and Psalm 32}

\section{The motif of not concealing one's sins but rather confessing them}

It was previously contended that Gosse correctly identified a literary connection between Proverbs 28:13 and Psalm 32:5. The Proverbs text reads: 'He who conceals (מכסה) his

21.See in this regard the sterling work of Mathys (1994). Mathys treats Psalm 33 as one of these meditative creations of post-exilic wisdom.

22.Murphy (1996:103) names (only!) Psalms 1, 32, 34, 37, 49, 112, and 128 as wisdom psalms. 
transgressions (פשעיו), will not prosper, but the one who confesses (מודה) and forsakes (them), will find mercy.'

This aphorism has connections with Psalm 32:5. In that verse, the author states:

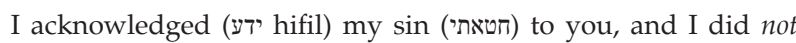
conceal (לא כסית) my iniquity (עוני); I said, 'I will confess (אודה) my transgressions (פשעי) to Yahweh,' and you forgave the iniquity of my $\sin ($ עון חטאת).

Proverbs 28:13 in fact seems to relate to the whole first stanza of Psalm 32, not only verse 5. Read together with Psalm 32:1, where the verb כסה ('to cover, conceal') and the noun פשעע ('transgression') are also used, as well as verses 3 and 4, where the poet describes his condition of suffering during the time when he kept silent (thus tried to conceal his sins and did not confess them as the Proverbs text prescribes), it seems possible that the author of the psalm text is applying the teaching found in Proverbs 28:13 to his own experience in the whole first stanza of the psalm. ${ }^{23}$ The three Hebrew words which reflect a literary relationship between Psalm 32 and Proverbs 28:13 are כסה ידע, 'to cover/conceal, 'offence/ iniquity,' and ידה (hiphil), 'to confess.' The only two texts in the Hebrew Bible where ידה in the hiphil and פשע are used together for the confession of sins are Proverbs 28:13 and Psalm 32:5, ${ }^{24}$ providing a strong argument for a literary relationship between the two on the grounds of a shared vocabulary, motif and content. The usual expression for the confession of sins uses ידה in the hithpael, ${ }^{25}$ whilst in the hiphil ('to make known') is also once used to express the confession of $\sin .{ }^{26}$

If knowledge of Proverbs 28:13 by the author of Psalm 32 is assumed, one can thus infer that the author of the psalm implies that he tried to conceal his sin by keeping silent about it and that he suffered as a result of this (he did not 'prosper' in the language of Proverbs). This carried on until he decided not to 'conceal' (כסה piel) his 'iniquity' (עוני) any longer, but

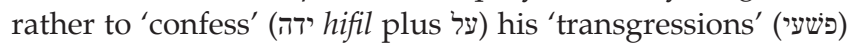
to Yahweh as Proverbs 28:13 advises, and that Yahweh then 'forgave' (נשוא) the 'iniquity' of his 'sin' (עון חטאתי), in other words, that he found mercy in the language of Proverbs. To have one's sins forgiven in Psalm 32 could therefore be viewed as the equivalent of 'finding mercy, obtaining compassion' (רחם pu'al) in Proverbs 28:13. ${ }^{27}$ Such a person is described as 'blessed' or 'happy' through the use of two beatitudes at the beginning of Psalm 32. The verb כסה is used twice (in vv. 1 and 5), and a polarity is formed between the

23.Plöger (1984:335) remarks that, for the interpretation of Proverbs $28: 13$, almost all exegetes refer to Psalm 32:3-5. The direction of influence is presumed to be from Proverbs to Psalm 32 in this contribution, however. Another interesting aspect of Psalm 32:1-5 is that it seems to reflect a literary connection with Psalm 38. The description of suffering because of sin in Psalm 38 have been 'telescoped' and summarised in Psalm 32.

24.This is also stated by McKane (1970:628).

25.For example, Levitikus 5:5; 16:21; 26:40; Numbers 5:7; Nehemiah 1:6; and Daniel 9:20.

26.Psalm 38:19, where עון is also used.

27.The use of the pual of רח in Proverbs 28:13 may be an indication that the teaching of Exodus $34: 6-7$ is reflected in this verse. Cf. the description of Yahweh as 3 in Exodus 34:6 with the promise of forgiveness in Exodus 34:7, and the combination of these in Psalm 78:38. positive use (in the qal passive, 'covered,' with Yahweh as the inferred subject of the action) and the negative use of the verb (in the piel perfect, 'I did not conceal,' with the suppliant as subject). Used with a negation, the negative meaning of the verb is turned into a positive statement. The two uses of in strophe A and C imply that the psalmist was in fact trying to conceal his transgressions during the time described in strophe B, when he kept silent.

It seems significant that Proverbs 28:14, the verse following the pronouncement about the prosperity of those who do not try to 'conceal' their sins, but rather 'confess' them, also begins with a beatitude: 'Blessed is the man (אשרי אדם) who always fears (מפחד), but whoever hardens his heart will fall into misfortune (רעה).'

The similarity of the beginning of this verse with the beginning of Psalm 32:2 (אשרי אדם) is conspicuous. What is more, the teaching of Proverbs 28:14 about obstinacy (hardening one's heart) also seems to be reflected in the second stanza of Psalm 32, seeing as Psalm 32:9-10 exhorts the reader or listener not to be like a horse or a mule which has no understanding and must be controlled with reins. ${ }^{28}$ The first stanza thus has a connection to Proverbs 28:13 and seems to apply its teaching to the life of the psalmist, whilst one strophe of the second stanza seems to have a connection to Proverbs 28:14, and possibly serves as an application of its teaching on obstinacy. ${ }^{29}$

Proverbs 28:13-14 indeed forms a proverbial pair, with verse 14 escalating verse 13 (Waltke 2005:417). The connection between them is that verse 13 a speaks of the impenitent and verse $14 \mathrm{~b}$ of the hardened sinner. The two inner cola, $13 \mathrm{~b}$ and $14 \mathrm{a}$, complete the chiastic arrangement: $13 \mathrm{~b}$ teaches forgiveness of sin by giving praise to God through confessing sin and abandoning it; verse 14 a teaches how to avoid sin in the first place by fostering fear for Yahweh (Waltke 2005:417):

Whoever conceals his transgressions will not prosper,

but he who confesses and forsakes (them) will obtain mercy.

Blessed is the person who fears (Yahweh) always,

but whoever hardens his heart will fall into calamity.

To try to conceal one's transgressions is therefore connected to hardening one's heart; to confess and forsake one's transgressions implies to 'fear' Yahweh always. An unusual expression is used to describe 'fear' of Yahweh in Proverbs 28:14, namely מפחד. There is no object for the verb in the verse, but it seems to express an attitude of meekness (in contrast to pig-headedness) before Yahweh. ${ }^{30}$ This information strengthens the impression that Psalm 32 was composed as a unity and that the problem which is addressed in the two stanzas together is that of obstinacy against the authority of

28.Lamparter (1961:162) makes a connection between the defiant silence of Psalm 32:3-4 and the obstinate self-will addressed in 9-10. He also stresses (p. 165) the causative particle ('Therefore...') which links the second stanza to the first in verse 6 .

29.Waltke (2005:417) refers to Van Leeuwen's remark that Proverbs 28:13-14 together 'echo vocabulary and themes from Psalm 32.' However, the influence probably extends from Proverbs 28 to Psalm 32, not vice versa. For Van Leeuwen's remark, cf. Clifford et al. (1997:238)

30.Stähli describes its meaning in Proverbs 28:14 as 'menschliche Ängstlichkeit und Vorsicht' (human anxiety and caution). Cf. Stähli (1976:413). This does not seem to be very helpful in view of the fact that he also describes the theological use of the root as often referring to the numinous fear of God (p. 412). 
Yahweh which causes one to refuse to confess transgressions. The opposite of such obstinacy would be respect for Yahweh which helps one to avoid calamity (רעה). The attitude which is encouraged is one of openness and complete trust in Yahweh. Incidentally, trust in Yahweh (and not in one's own heart) is mentioned in Proverbs 28:25-26 בוטח על-יהוה) (הבוה ביהוה) and also

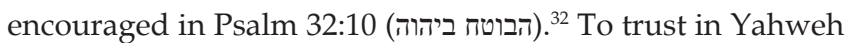
is linked to 'walking' in wisdom (חכמה) in the combination of Proverbs 28:25-26, whilst Psalm 32:9 also exhorts to wisdom (הבין). The expression to 'fall into calamity' occurs also in Proverbs 17:20 and the warning which is given there has an indirect bearing on Psalm 32. Proverbs 17:20 says: 'The one who has a twisted heart will not find good, and one who is dishonest with his tongue will fall into calamity.' This may have significance for understanding Psalm 32:2, where the one 'in whose spirit there is no deceit' is included amongst the blessed. ${ }^{33}$ Psalm 32:1-5 thus encourage the righteous to avoid any attempt to deceive Yahweh, to be frank instead about one's transgressions, and to confess one's guilt.

The verb נשא 'to lift, carry,' is twice used in the sense of the forgiveness of sins in Psalm 32 (vv. 1 and 5). It is used a fair number of times also in other places in the Hebrew Bible to express the forgiveness of sins, occurring with all three synonyms for sin with which it is also closely associated in this psalm. The same does not apply, however, to the verb כסה, 'to cover' in the positive sense of forgiveness. Only three verses in the Hebrew Bible use כסה in a way comparable to that in Psalm 32: Nehemiah 3:37, where Nehemiah asks God not to 'cover (forgive)' the guilt (עון) of Sanballat and Tobiah; Job 31:33, where Job protests that he had not 'concealed' (כסיתי) his transgressions (פשעי) like Adam by 'hiding' (לטמון) his iniquity (עון) in his bosom; and Psalm 85:3, where Yahweh is thanked for forgiving (נשא) the iniquity (עון) of his people, for having 'covered' (כסה) all their sins (חטאה).

The Job use of כסה provides a close parallel to Psalm 32:5 where the psalmist says that he did not 'conceal' (כסיתי) (any longer) his iniquity (עון) when he decided to confess. ${ }^{34}$ The connection with this wisdom context in Job can probably be traced to the influence of Proverbs on both Job ${ }^{35}$ and Psalms, given that Proverbs, which has about $12 \%$ of all instances of כסה, uses it to describe the 'concealment' of quite a number of abstract things, inter alia violence (by the mouth of the wicked in 10:6 and 11); hatred (by one who lies in 10:18); transgressions, פשעים, (by love in 10:12); any matter, דבר, (by the person who is trustworthy in 11:13); dishonour, קלון, (by the wise person who ignores it in 12:16); and transgression, פשיון,

31.Cf. also the opposite of trust in Yahweh, namely trust in one's own heart in verse 26 .

32.In Proverbs 28:26, the opposite of trusting in one's own heart, thus to trust in Yahweh, is described as to 'walk in wisdom.' Psalm 32 similarly urges the faithfu not to be 'unwise' and to take instruction on the way one has to follow.

33.Cf. also the parallel description of the 'righteous' in Psalm 32:11 as the 'upright of heart.'

34.The difference is that Job asserts in chapter 31 that he has no iniquity to conceal, whilst the author of Psalm 32 implies that it is not possible to be without guilt.

35.See in this regard the assertion in Job 31:23 that he (Job) did not transgress because he was in terror (פחד) of calamity (איד is used instead of רעה as in Pr 28:14) from God and could not face God's majesty. This clearly reflects the attitude propagated
in Proverbs $28: 14$, although Job is doing the exact opposite of what is advised in in Proverbs 28:14, although Job is doing the exact opposite of what is advised in Proverbs 28:13, whilst he claims to be following the advice. (by one who is seeking love in 17:9); whilst it is also used of hate covering itself in deception, משאון, (in 26:26). It seems to be a popular expression for 'hiding' something in Proverbs, either in a positive or a negative sense and this is also the way in which it is used in Psalm 32:1 (positive) and Psalm 32:5 (negative, similar to Job 31:33). ${ }^{36}$ The two verses in Proverbs that speak of the 'hiding' of transgressions because of love, thus forgiving someone, provide a clear wisdom background for the positive use of כסה in Psalm 32.

The conclusion from this investigation must be that Psalm $32: 1-5$ and 9 constitute a response to Proverbs 28:13-14, and that Job 31 as a whole most probably represents a critical response to both these texts. ${ }^{37}$

\section{The motif of Yahweh as wisdom teacher}

In Psalm 32:8 and 9 (strophe E), Yahweh is speaking and he adopts the role of a wisdom teacher. The wisdom specialisation verb שכל (hiphil 'to make wise') is used, and Yahweh announces that he would like to show the way (ירה hiphil with דרך) which the suppliant should go. Hossfeld notes that Psalm 16:11 and Psalm 25:8 and 12 provide parallels to this, whilst the intention of Yahweh to 'counsel' (יע') the suppliant has a parallel in Psalm 16:7 (Hossfeld 1993:205). According to Psalm 25:8, Yahweh instructs (יורה) sinners in the way (בדרך); in Psalm 25:12 it is the man who fears Yahweh whom he will instruct (בדרך) (בדר) in the way (ברור) he should choose; and in Psalm 27:11 the psalmist prays that Yahweh would teach (הורני) him his way (דרכך) and lead him on a level path because of his enemies. However, these psalms, which were composed by circles of wisdom-inspired devotees, probably display the same connection with Proverbs as does Psalm 32:8.

In Proverbs 4:11 the wisdom teacher exhorts the student by saying, 'I teach you (ירה hiphil) in the way (דרך) of wisdom, I let you walk in the paths of uprightness (ישר).' In Psalm 32, Yahweh adopts the same stance as teacher, although the subject of teaching is not wisdom as in Proverbs 4:11, but the way the suppliant should go, similar to Psalm 25:8. The road metaphor, however, permeates the whole context of Proverbs 4:11-27. The reference to a 'level path' in Psalm 27:11, for instance, has a clear connection to Proverbs 4:26, where the student is instructed to 'level' the path of his feet. Proverbs 4:11-27 contrasts the road of the wicked with the road of the righteous (vv. 18-19). Psalm 32 also contrasts the righteous and the wicked: The suffering of the wicked is contrasted with the experience of Yahweh's covenant love by those who trust in him and with the joy of the righteous (vv. 10-11). What is also significant in this Proverbs context, is that the road of wisdom is called the 'paths of uprightness,' whilst the

36.Cf. also the denial by Job that he 'kept silence' (דמם is used, not (זרש in Job 31:34 It may be possible that the author of Job is responding to both Proverbs 28:13-14 and Psalm 32:1-5.

37.In Job 31, the character Job is arguing climactically that he is innocent with regard to transgression of any nature, be it sexual (vv. 1 and 9); deceit (v. 5); human rights (vv. 13,16-21 and 32); trust in gold and riches instead of on God (vv. 24-25); worship of idols (vv. 26-27); or joy about the downfall of an enemy (vv. 29-30). his sin 'like Adam' (who hid himself from God). It would seem that this conceal his sin 'like Adam' (who hid himself from God). It would seem that this speech is a reaction to both Proverbs 28:13-14 and Psalm 32's application of this wisdom teaching. 
community of worshippers is called the 'upright in heart' in Psalm 32:11. The words of the wisdom teacher are described in Proverbs 4:22 as healing for the whole body of those who find it. There is a conspicuous link to Psalm 32, seeing as it is implied that the suppliant experienced healing when he complied with the wisdom teaching of Proverbs 28:13-14 by confessing his sins.

The verb יע' in the hiphil ('to counsel') also has wisdom connections. One may point to the prevalence of the cognate word עצה, 'counsel,' in wisdom psalms, Job and Proverbs. ${ }^{38}$ The verb יעי also occurs in Proverbs 13:10 where it says, 'Insolence only leads to conflict; but those who take advice (נועצים) are wise.' This is pertinent to Psalm 32, given that the author also wants to stress the point that the 'pious,' those who 'trust in Yahweh,' the 'righteous,' and the 'upright in heart' should take counsel from Yahweh. Negatively formulated, they should not be like a horse or a mule, animals that can sometimes be obstinate because they are 'without understanding,' thus unwise (v. 9). ${ }^{39}$

\section{The use of animal imagery in Psalm 32}

Psalm 32:9 possibly also provides a direct link to Proverbs.

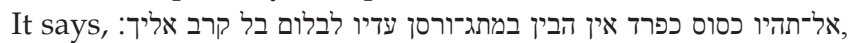
‘Be not like a horse $e^{40}$ or a mule, without understanding, the going of which must be curbed with bridle and rein, or it will not come near you.' Proverbs 26:3 says, שוט לסוס מתג לחמור ושבט 'A whip is for the horse, and a bridle for a donkey, and a rod for the back of fools.' It may be argued that there are only two words which occur in both texts, namely 'horse' and 'bridle.' Yet it is probable that this verse in Proverbs served as the inspiration for Psalm 32:9, seeing as the two animals mentioned, a horse and a donkey, are associated in the Proverbs text with a fool, someone characterised through his lack of understanding. Whilst 'whip' and 'bridle' are mentioned as instruments to make these animals do what one wants them to do, the psalm text refers to 'bridle' and 'rein.' The image of the whip would not have been fitting in Psalm 32:9, given that it is too harsh to compare the pious to fools, although the related concept of 'lack of understanding' is indeed used in the psalm text, ${ }^{41}$ with the implication that suffering in body and soul is equivalent to Yahweh's keeping a rein on the upright. The use of instruments to bring animals close to one is the equivalent of instruments for forcing similar animals to go where needed. The psalm text wants to emphasise the importance of a close relationship between Yahweh and the godly whilst on the way to life's destination 38.For example, Psalms 1:1; $33: 10$ and $11 ; 73: 24 ; 119: 24 ; 11$ times in Proverbs and 8 times in Job of the 92 occurrences in total.

39.The author of the (wisdom) psalm, Psalm 73, also considers the time of his rebellion a time of stupidity and ignorance, with him being like a 'beast' toward Yahweh (73:22). He later discovered that the highest form of happiness is to be in the presence of Yahweh, being guided though the counsel (עצה) of Yahweh (73:23-24).

40.The word 010, 'horse,' provides a keyword connection between Psalm 32:9 and the adjacent Psalm 33:17. They have connections with separate contexts in Proverbs, however, given that Psalm 33:17 clearly reflects the teaching of Proverbs 21:31, whilst Psalm 32:9 reflects the teaching of Proverbs 26:3.

41.There is a close association between ביל ('fool') and ('to understand') in Proverbs $8: 5,14: 8 ; 14: 33 ; 15: 14 ; 17: 10 ;$ and $17: 24$. The only two remaining texts where the two words occur together, namely Psalm 92:7 and 94:8, were probably also influenced by wisdom. (cf. the use of קרב, 'to approach,' in Psalm 32:9 and the use of of to surround or encircle protectively in vv. 7 and 10). ${ }^{42}$

A similar comparison between the worshipper of Yahweh and a foolish and ignorant animal is also made in Psalm ואני־בער ולא אדע בהמות הייתי עמך: 73:22.43 This verse reads, '(When my heart was embittered, and I was pierced within), then I was foolish and ignorant, I was like a beast near you.' Psalm 73 is also a wisdom psalm and discusses the problem of suffering of righteous people, in view of the fact that the wicked ignore Yahweh indignantly and still prosper. The conclusion of the psalmist is that physical suffering is of no consequence as long as one can be 'close' to Yahweh (note the use of קרבה in Psalm 73:27-28). It is noteworthy that Psalm 32 also considers the aspect of 'being close,' seeing as Yahweh complains about worshippers who are without understanding and 'will not come close,' קרב, unless 'bridled.' The implication is that suffering could sometimes be the instrument which Yahweh uses to give understanding to obstinate believers, to bring them into a close relationship with him once again. ${ }^{44}$ The options are to be guided by a bridle, through the pressing hand of Yahweh, or through instruction, walking on the path of life under the benevolent eye of Yahweh. ${ }^{45}$

\section{The genre of Psalm 32}

As a whole, it seems that the objective of the author of Psalm 32 was to offer his own religious experience to the benefit of all who worship Yahweh. This coincides with one of the objectives of a psalm of thanksgiving, but in this case, the psalmist simply uses some elements of the genre for his own purpose. The author also made use of the typical representation found in individual laments about bodily and spiritual suffering as a result of isolation from Yahweh and fellow believers. Because of his experience, the psalmist can advise other believers to worship Yahweh whilst he is to be found. If they do this, it will result in the individual worshipper being protected by Yahweh during a crisis (vv. 6-7). But worshippers can also expect to be integrated again in the community of faithful (v. 7). This is described, through the chiastic form of the psalm, as the result of confessing one's guilt.

The objection may be raised that sections of the psalm are presented as a prayer; where the direction of communication is from a human to Yahweh (vv. 4-7), which does not fit into a wisdom-teaching psalm. This is also true of some of the other wisdom psalms, however, such as Psalms 25, 73 and 119,

42.This use of 'surround, encircle' in Psalm 32:10 shows conspicuous similarity with Deuteronomy 32:10, 'He (Yahweh) found him (Israel) in a desert land, and in the howling waste of the wilderness; he surrounded him, he protected him, he guarded him like the apple of his eye.'

43.Van der Ploeg (1973: 210) also refers to Psalm 49:13 and 21 ('animals that perish').

44.The same idea is expressed by Elihu in Job 33:19: Suffering (מכמבוב) on a sick-bed which causes continual strife in a person's bones (עצמיו) is used as a second option (in addition to a dream) by God to deter that person from a certain action, so that he can save him from certain death.

45.Lamparter (1961:166) points out the similarity of using bit and bridle with what happens to the obstinate Sennacherib whom Yahweh takes away on the road by which he came, against his will and with a hook in his nose and a bit in his mouth (Is 37:29). 
and there are conspicuous similarities between Psalm 32 and these wisdom psalms. The opening beatitudes already serve as an indication that the psalm as a whole was intended for instruction. Similar to what happens in Psalm 73, the author expects that fellow believers will take instruction from his experience, his address to Yahweh and Yahweh's response to this. Furthermore, Yahweh is clearly portrayed in the psalm as the instructor and teacher of the suppliant as well as other upright people (vv. 8-9). Although this is stated in a first person speech by Yahweh himself, the contents do not differ from similar statements in Psalm 25:9 and $12 .{ }^{46}$ Only one strophe (B) speaks of suffering and the dominant tone of the psalm is one of gratefulness and joy: Blessedness in having experienced forgiveness (1-2), the expression of thanks for forgiveness (5b), the encouragement of trust in Yahweh (7), and a call to jubilation and joy (11) (Van Uchelen 1971:213).

On the basis of literary connections with Proverbs and similarities with Psalm 25 and Psalm 73, the conclusion must be that Psalm 32 is a wisdom psalm. Teaching which is very similar to that given in Psalm 25 is presented in a different mould in order to create variation and to involve the audience. In addition to the twice-repeated formula of blessing in verses 1 and 2, exhortation of the reader and listener is effected with the help of a confession by the author that he had to be 'coerced' by the hand of Yahweh towards the confession of his own guilt. ${ }^{47}$ The image of an unwilling horse or mule is used in the second stanza to increase the admonitory effect. The simile of bit and bridle which are used to tame unwilling animals fits the learning curve of the worshipper who had to be convinced through Yahweh's 'hand' which rested heavily on him. In a direct address to the psalmist, and subsequently the whole community of faithful (using a plural jussive form in v. 9), Yahweh also offers to act as a coach and guide on the way of life of members of the audience, and he himself exhorts the audience to abandon rebellious conduct.

\section{Conclusion}

There can be little doubt that Psalm 32 is a wisdom text with the objective of instructing worshippers, rather than a modified psalm of thanksgiving that was composed or used by someone who was restored from illness. The wisdom characteristics in the psalm are not foreign bodies; they rather form part and parcel of a finely structured wisdom composition through which the author intended to provide instruction to fellow believers. In doing so, he was applying the teaching also found in Proverbs. The psalm seems to give an application of the contents of Proverbs 28:13-14, demonstrating through the personal experience of the author that the idea that one can hide one's transgressions from Yahweh is in itself the most serious transgression and that it is foolish to harden one's heart in the face of suffering. The

46.In both psalms the construction in the hiphil with is used. Cf. Psalm 25:12 and Psalm 32:8. The same idea is also expressed with different words in Psalm 25:4 and 5.

47.Cf. the beginning of Psalm 119 with a similar repeated formula of blessing, and the idea that it is good that the suppliant was afflicted, seeing as it helped him to learn the statutes of Yahweh (v. 71). psalmist assures his audience that Yahweh is merciful and willing to forgive transgressions. In this he also applies the aphorism about animals' lack of understanding found in Proverbs 32:9. He insists that Yahweh prefers to have a close relationship with the pious, the righteous, and the upright in heart. Yahweh offers this relationship as a gift to those who are not stubborn but willing to accept his guidance on the path of life and trust in him wholeheartedly, complying with the call to listen to the wisdom teacher found in Proverbs 4:11. The literary context for the interpretation of Psalm 32 seems to be Proverbs and wisdom psalms. The correspondence of these psalms and certain texts in Job with Psalm 32 can best be explained as a mutual indebtedness of certain psalms and Job to the book of Proverbs.

\section{Acknowledgements Competing interests}

The author declares that he has no financial or personal relationship(s) that may have inappropriately influenced him in writing this article.

\section{References}

Barbiero, G., 1999, Das erste Psalmenbuch als Einheit, eine synchrone Analyse von Psalm 1-41, Europäischer Verlag der Wissenschaften, Frankfurt am Main. (Österreichische Biblische Studien 16).

Clifford, R.J., Van Leeuwen, R.C., Towner, W.S., Weems, R.J. \& Kolarcik, M., 1997 Introduction to wisdom literature, the book of Proverbs, the book of Ecclesiastes, the Song of Songs, the book of Wisdom, the book of Sirach, Abingdon, Nashville. the Song of Songs, the book
(New Interpreter's Bible 5).

Delkurt, H., 2010, 'Psalm 32: Gerecht aufgrund Vergebung der Sünden,' in P. Mommer \& A. Scherer (Hrsg.), Geschichte Israels und deuteronomistiches Geschichtsdenken, Festschrift zum 70. Geburtstag von Winfried Thiel, pp. 46-59, Ugarit-Verlag, Festschrift zum 70. Geburtstag von Winfried
Münster. (Alter Orient und Altes Testament 380).

Gosse, B., 2008, L'influence du livre des Proverbes sur les rédactions bibliques à l'époque perse, Gabalda, Paris.

Gunkel, H., 1986, Die Psalmen, übersetzt und erklärt, Sechste Auflage, Vandenhoeck \& Ruprecht, Göttingen.

Hossfeld, F.-L., 1993, 'Psalm 32, Gnade und Lob der Vergebung,' in F.-L. Hossfeld \& E. Zenger (Hrsg.), Die Psalmen I: Psalm 1-50, pp. 200-205, Echter Verlag, Würzburg. (Kommentar zum Alten Testament mit der Einheitsübersetzung).

Hossfeld, F.-L. \& Zenger, E., 2007, Psalmen 51-100, Herder, Freiburg/Basel/Wien. (Herders Theologischer Kommentar zum Alten Testament).

Kraus, H.-J., 1972, Psalmen 1. Teilband, Vierte Auflage, Neukirchener, NeukirchenVluyn. (Biblischer Kommentar zum Alten Testament 15/1).

Lamparter, H., 1961, Das Buch der Psalmen I: Psalm 1-72, Calwer Verlag, Stuttgart. (Die Botschaft des Alten Testaments 14).

Mathys, H.-P., 1994, Dichter und Beter: Theologen aus spätalttestamentlicher Zeit, Universitätsverlag Freibourg, Fribourg. (Orbis Biblicus et Orientalis).

McKane, W., 1970, Proverbs: A new approach, SCM Press, London. (The Old Testament Library).

Murphy, R.E., 1996, The tree of life: An exploration of biblical wisdom literature, 2nd edn., William B. Eerdmans, Grand Rapids.

Nötscher, F., 1953, Die Psalmen, Echter-Verlag, Würzburg. (Echter Bibel, Alte Testament).

Plöger, O., 1984, Sprüche Salomos (Proverbia), Neukirchen, Neukirchener Verlag. (Biblischer Kommentar Altes Testament 17).

Potgieter, J.H., (in press), 'The structure and homogeneity of Psalm 32', HTS Teologiese Studies/Theological Studies 70(1), Art. \#2725.

Reichenbach, G., 2011, Gültige Verbindungen, Eine Untersuchung zur kanonischen Bedeutung der innerbiblischen Traditionsbezüge in Sprüche 1 bis 9, Evangelische Verlagsanstalt, Leipzig. (Arbeiten zur Bibel und ihrer Geschichte 37).

Seybold, K., 1996, Die Psalmen, J.C.B. Mohr, Tübingen. (Handbuch zum Alten Testament I/15)

Stähli, H.-P., 1976, פחד7 PHD beben', in E. Jenni \& C. Westermann (Hrsg.), Theologisches Handwörterbuch zum Alten Testament, Zwei Bände, Band II, pp. 411-413, Chr. Kaiser Verlag, Munich.

Van der Ploeg, J.P.M., 1973, Psalmen Deel I: Psalm 1 T/M 75, J.J. Romen \& Zonen, Roermond. (De Boeken van het Oude Testament).

Van Uchelen, N.A., 1971, Psalmen deel I: (1-40), Callenbach, Nijkerk. (Prediking op het Oude Testament). 
Waltke, B.K., 2005, The Book of Proverbs: Chapters 15-31, William B. Eerdmans, Grand Rapids.

Weber, B., 2001, Werkbuch Psalmen I: Die Psalmen 1 bis 72, Kohlhammer, Stuttgart.

Weber, B., 2010, Werkbuch Psalmen III: Theologie und Spiritualität des Psalters und seiner Psalmen, Kohlhammer, Stuttgart.

Weiser, A., 1955, Die Psalmen, Erster Teil: Psalm 1-60, 4. Auflage, Vandenhoeck \& Ruprecht, Göttingen. (Das Alte Testament Deutsch 14).
Whybray, N., 1996, Reading the Psalms as a Book, Sheffield Academic Press, Sheffield. (Journal for the Study of the Old Testament Supplement Series 222).

Willmes, B., 1996, Freude über die Vergebung der Sünden: Synchrone und diachrone Analyse von Psalm 32, Verlag Josef Knecht, Frankfurt am Main. (Fuldaer Hogschulschriften 28).

Wilson, G.H., 2002, Psalms Volume 1, Zondervan, Grand Rapid. (The NIV Application Commentary). 